\title{
Effects of Three Conservation Tillage Strategies on Yields and Soil Health in a Mixed Vegetable Production System
}

\author{
Jeffrey R. Pieper ${ }^{1}$ and Rebecca Nelson Brown ${ }^{3}$ \\ Department of Plant Sciences and Entomology, University of Rhode Island, \\ Kingston, RI 02881 \\ José A. Amador ${ }^{2}$ \\ Department of Natural Resources Science, University of Rhode Island, \\ Kingston, RI 02881
}

Additional index words. cover crops, soil organic matter, microbial respiration, organic nitrogen, living mulches, strip tillage

\begin{abstract}
Most vegetable farms in southern New England market directly to consumers and are characterized by high crop diversity and intensive cultivation. Growers rely on tillage to prepare fields for planting and control weeds, but are concerned about the negative effects of tillage on soil health. This study evaluated three tillage reduction strategies in a market garden system producing tomatoes, melons, cucumbers, cabbage, carrots, and lettuce. Treatments of strip tillage into a killed cereal rye (Secale cereale) cover crop mulch, perennial white clover (Trifolium repens), and ryegrass (Lolium perenne) living mulch between planting rows, and annual crimson clover (Trifolium incarnatum) living mulch interseeded between vegetable rows were established in 2010 and compared over 3 years to a control system using tillage to maintain bare ground between rows. Treatments were evaluated for effects on vegetable yield and soil biological, chemical, and physical properties. The strip tillage treatment was the most effective at promoting soil health, resulting in significant increases in soil aggregate stability, potentially mineralizable nitrogen, active soil carbon, and microbial activity relative to the control, and significant decrease in loss of soil organic matter. However, it was not effective for production of vegetables, with the strip-tillage plots having the lowest yields throughout the study. The perennial living mulch treatment produced yields of carrots, melons, and cucumbers similar to the control yields, but reduced yields of tomatoes, cabbage, and lettuce. Microbial respiration was significantly higher than in the control, and nitrate levels, and loss of soil organic matter were significantly lower. The annual living mulch treatment produced yields similar to the control for all crops, and soil health was similar to the control for all variables except soil nitrate, which was significantly higher than the control. Perennial living mulch shows the most promise for improving soil health while maintaining yields in some vegetable crops, but challenges remain in preventing competition between vegetables and living mulches.
\end{abstract}

Tillage is a major cause of soil degradation in agricultural systems, leading to compaction, erosion, loss of organic carbon, and disruption of soil ecosystem processes (Magdoff and van Es, 2009). The majority of commodity crop acreage in the United States is managed with conservation tillage methods (Horowitz et al., 2010), but vegetable growers continue to rely on conventional tillage for bed preparation and weed control, particularly on diverse, high-intensity market

Received for publication 16 Dec. 2014. Accepted for publication 13 Oct. 2015

This research was supported by a grant from Northeast SARE (LNE10-293) to RNB, and by the Rhode Island Agricultural Experiment Station. ${ }^{1}$ Graduate Student and Associate Professor. Current address: Colorado State University Cooperative Extension, Eagle, CO 81631.

${ }^{2}$ Professor

${ }^{3}$ Corresponding author. E-mail: brownreb@uri. edu. farms (Magdoff and van Es, 2009). In southern New England (Connecticut, Rhode Island, and Massachusetts), $\approx 17 \%$ of farms produce vegetables for sale and $82 \%$ of these are market farms (USDA, 2012). These farms average 4.2 ha in vegetables, and growers strive to market freshly harvested field-grown produce from May through November. Vegetable growers and researchers are aware of the negative impacts of tillage, and multiple studies have attempted to adapt commodity crop conservation tillage methods for use in vegetable systems (Hoyt et al., 1994; Nair et al., 2014). Previous studies have focused on systems producing a single vegetable crop for wholesale or processing markets, and most of the very limited adoption of conservation tillage has been in these systems, particularly processing tomatoes (AbdulBaki and Teasdale, 2007; Mitchell et al., 2009, 2012). Conservation tillage increases carbon and organic matter in surface soils (to $15-\mathrm{cm}$ depth) as well as active microbial biomass and aggregate stability, and alters availability of extractable nutrients (Baker et al., 2007; Stubbs et al., 2004). However, reducing tillage may increase problems with root diseases and weeds (Stubbs et al., 2004). Integration of cover crops into low-biomass cropping systems magnifies the beneficial effects of tillage reduction (Havlin et al., 1990). In conversations with growers in southern New England we have learned that they are interested in reducing tillage and improving soil health, but are unsure how tillage reduction and cover cropping would fit into their diverse production systems, particularly without the use of herbicides. The objective of this study was to evaluate three reduced tillage and cover crop strategies in an intensive mixed vegetable system.

\section{Methods}

\section{Trial design and management}

Field description. The study was established in Spring 2010 on 0.5 ha of Bridgehampton silt loam soil (coarse-silty, mixed, active, and mesic Typic Dystrudepts) at the University of Rhode Island's Greene H. Gardener Crops Research Farm in Kingston, RI $\left(41^{\circ} \mathrm{N}\right.$ latitude; USDA hardiness zone 6 with mild summers). Before study establishment, the field was planted to rye (S. cereale) with no tillage for 18 months.

Plot layout. The study was laid out as a randomized split-plot design with three replications. The three conservation tillage treatments and the conventional tillage control formed the main plots, with the vegetables as subplots. Main plots were $10 \mathrm{~m} \times 30 \mathrm{~m}$; the same area was used for the entire study. Each main plot was subdivided into six, $1.5-\mathrm{m}$-wide rows. The two outside rows were maintained as buffers between plots, whereas the four interior rows were planted to vegetables. Every year the vegetable crops shifted one row to the east, with the fourth row becoming the first, to eliminate the use of the same beds for the same crops over multiple years. Data are reported for the 2011 and 2012 growing seasons.

Trial management. Irrigation was provided through drip tape (Aqua-traxx; The Toro Company, Bloomington, $\mathrm{MN}$ ) with $30-\mathrm{cm}$ emitter spacing. Cucurbit and tomato beds had one line of drip tape, whereas beds for cabbage had two lines. The trial was irrigated when soil became visibly dry at a depth of $10 \mathrm{~cm}$ within the root zone. Organic fertilizer (Seablend 7-5-5; Ocean Organics, Waldoboro, ME) was banded before planting at rates of $45 \mathrm{~kg} \mathrm{~N} / \mathrm{ha}$ in 2011 and $70 \mathrm{~kg} \mathrm{~N} / \mathrm{ha}$ in 2012. In 2012, crops were also side-dressed with $15 \mathrm{~kg} \mathrm{~N} /$ ha on July 10 . Additional fertility was provided by fertigation with fish emulsion (Organic Gem 3-30.3; Advanced Marine Technologies, New Bedford, MA) every 7 to $10 \mathrm{~d}$ at a rate of $47 \mathrm{~L} \cdot \mathrm{ha}^{-1}$. Weeds within the planting row (between the plants) were controlled by hand hoeing and pulling in all treatments. Copper sulfate (Kocide 3000; DuPont, Wilmington, DE) and chlorothalonil (Bravo Weatherstik, Syngenta Crop Protection, Greensboro, NC) 
were used to prevent disease in the tomatoes. Lepidopteran pests in the cabbage and tomatoes were controlled with Bacillus thuringiensis ssp. kurstaki (Dipel DF; Valent USA, Walnut Creek, CA); Agribon-15 rowcovers (AVINTIV; Charlotte, NC) were used to protect the cucurbits from cucumber beetles. Pesticides were applied based on scouting thresholds and weather indicators as recommended in the New England Vegetable Management Guide (Howell, 2010). Harvested crops were graded, weighed, and counted. Marketability was determined based on standards for direct retail, rather than established wholesale grades. Produce for direct retail needs to be free of damage and disease, but there are no specific requirements for size or shape.

\section{Treatments}

Strip tillage. In October, crop residues were incorporated by disking and rye was seeded; the seeding rate was $123 \mathrm{~kg} \cdot \mathrm{ha}^{-1}$ in 2010 and $184 \mathrm{~kg} \cdot \mathrm{ha}^{-1}$ in 2011 and 2012. The rye was killed at anthesis with a frontmounted roller-crimper (I \& J Manufacturing, Gap, PA). Planting strips (30-cm-wide) were cut in a killed rye cover crop with a custom-built zone tillage unit consisting of a Monroe Tufline ${ }^{T M}$ 2S-24-60 subsoiler (Tufline, Columbus, MO) with Unverferth ${ }^{\circledR}$ zone strip coulters and roller basket (Unverferth Manufacturing Co., Kalida, $\mathrm{OH}$ ).

Perennial living mulch. A permanent bed system consisting of 1-m-wide planting beds separated by $0.5-\mathrm{m}$-wide strips of living mulch was established in May 2010. A 10:1 mixture of turf-type perennial ryegrass $(L$. perenne) and Dutch white clover (T. repens) was seeded at a rate of $30 \mathrm{~kg} \cdot \mathrm{ha}^{-1}$ for the living mulch. In October of each year, the planting beds were rototilled with a walkbehind tiller and seeded with cereal rye at a rate of $123 \mathrm{~kg} \cdot \mathrm{ha}^{-1}$ using a drop seeder. The following spring, the rye was mowed and the beds were rototilled with a walk-behind tiller to prepare them for planting. During the growing season, the perennial living mulch was mowed to control weeds.

Annual living mulch. The field was prepared for planting by moldboard plowing followed by disking. Vegetables were planted in May, and overseeded with crimson clover (T. incarnatum) at a rate of $8 \mathrm{~kg} \cdot \mathrm{ha}^{-1}$ in June. The area between vegetable rows was mowed to control weeds, with the mower blade set to just above the height of crimson clover. The crimson clover was allowed to overwinter, and incorporated before spring planting.

Conventional tillage control. The field was prepared for planting by moldboard plowing to incorporate the rye cover crop as a green manure, followed by disking. Five planting beds, each $1.5 \mathrm{~m}$ in width, were created. After planting, weeds were controlled by rototilling. In October, the field was disked to incorporate residue and seeded with cereal rye at $123 \mathrm{~kg} \cdot \mathrm{ha}^{-1}$.

\section{Vegetable crops}

Tomato. Six-week-old greenhouse-grown transplants of determinate slicing tomatoes were transplanted by hand into single-row beds with $60 \mathrm{~cm}$ between plants. Plants were trellised using the stake-and-weave method, but were not pruned. Fruit was harvested when fully ripe. Multiple determinate slicing tomato cultivars were planted each year, with each experimental plot receiving the same number of plants of each cultivar. The 2011 cultivars were the orange-fruited cultivar Orange Blossom and the red-fruited cultivars Celebrity and Voyager. In 2012, the cultivars were Polbig, Celebrity, and Valley Girl, all of which have red fruit. All tomato seed was purchased from Johnny's Selected Seeds (Winslow, ME). Yield data are the sum of all cultivars each year.

Cabbage. The full-season green cabbage 'Royal Vantage' was grown from seeds provided by Rupp Seeds Inc. (Wauseon, OH). In 2011, cabbage was hand seeded on the 3rd of June. Two rows of plants were established in each bed, with $75 \mathrm{~cm}$ between rows and $30 \mathrm{~cm}$ between plants in the row after thinning. The 2012 crop was established on June 18 using 4-week-old greenhouse-grown transplants at the same spacing as in 2011. Cabbage was harvested when the heads in the control plots reached full size; at this time, all heads with diameter greater than $9 \mathrm{~cm}$ were harvested from all treatments.

Cucurbits. The cucurbit rows were divided into six subplots, alternating 'Diplomat' Galia melon and 'Marketmore 76' slicing cucumber down the row. Seed was purchased from Johnny's Selected Seeds. Plots were established using 4-week-old greenhouse-grown transplants placed $60 \mathrm{~cm}$ apart with one row per bed. Beds were covered with black plastic mulch in all treatments except strip tillage. Plastic mulch is a standard practice for production of melons and cucumbers in New England. Cucurbits were covered with Agribon-15 rowcover supported on wire hoops from transplant to anthesis for protection against striped cucumber beetle (Acalymma vitatum). Cucumbers were harvested when they reached $20 \mathrm{~cm}$ in length, and melons were harvested at full slip.

Carrot. Seed of the early Nantes cultivar Nelson were purchased from Johnny's Selected Seeds. Carrots were seeded May 28 of each year using a push seeder, with four rows per bed and $15 \mathrm{~cm}$ between rows. In 2011, an Earthway Seeder (Earthway Products Inc., Bristol, IN) was used, and in 2012, a Jang one-row Hand Seeder (distributed in the United States by Mechanical Transplanter Company, Holland, MI) was used. The stand was thinned to $1 \mathrm{~cm}$ between plants in the row. Carrots shared a plot with lettuce. In $2011,15.5 \mathrm{~m}$ of carrots were seeded, but the planting was reduced to $10 \mathrm{~m}$ in 2012 to allow additional succession plantings of lettuce. Carrots were dug by hand in October of each year.

Lettuce. Lettuce ('Harris Blend', Harris Seeds, Rochester, NY) was grown for harvest 5 weeks after seeding as salad mix and was planted using a six-row seeder (Johnny's Selected Seeds) with two passes per bed for a total of 12 rows with $5 \mathrm{~cm}$ between rows and $1 \mathrm{~cm}$ between plants in the row. A $10-\mathrm{m}$ section was seeded in each plot on May 28, followed by additional $3-\mathrm{m}$ sections at 2-week intervals until 15 Aug. In 2011, beds were lightly cultivated to prepare for succession plantings. A handheld flame weeder (Red Dragon, Flame Engineering, Inc., Lacrosse, KS) was used to create stale seedbeds in 2012, with each section burned twice before seeding. After seeding, plots were covered with Agribon-15 floating rowcover for protection from voles. Lettuce plantings were irrigated daily until the first true leaves were visible.

\section{Soil health}

A comprehensive soil health analysis was conducted in April of each year using the Cornell Soil Health Test, which evaluates soil aggregate stability, available water capacity, surface and subsurface hardness, organic matter, active carbon, potentially mineralizable nitrogen, root health, $\mathrm{pH}$, extractable phosphorus, extractable potassium, and minor elements (Idowu et al., 2009). Samples of the top $15 \mathrm{~cm}$ of the soil profile from throughout the plot area were collected each year $(2010,2011,2012$, and 2013) before the start of the growing season, following the Cornell protocol (Gugino et al., 2009). The initial sampling in 2010 was conducted in the three replication blocks to provide a set of baseline conditions. For the remaining years, each main plot was sampled individually. All samples were sent to Cornell University's Nutrient Analysis Laboratory (Ithaca, NY) for evaluation.

The Cornell Soil Health Test is intended to monitor soil characteristics that are relatively stable over the course of the growing season, but change over a period of years. Soil respiration and nitrate levels vary over the course of the growing season and are not included in the annual test. These were determined on biweekly soil samples collected May-November 2011 and 2012. Forty-eight sampling points were established across the field, with each treatment having four sampling points in each block, randomly placed in the tomato and lettuce subplots. Six soil core samples to a depth of $15 \mathrm{~cm}$ were collected from each sampling site on each date. The samples were combined and dried for $36 \mathrm{~h}$ at $50{ }^{\circ} \mathrm{C}$. Dried samples were crushed using a mortar and pestle, and hand shaken for $20 \mathrm{~s}$ to pass a 250 -micron mesh sieve. Soil respiration was measured using the Solvita Soil $\mathrm{CO}_{2}$ Respiration kit (Woods End Laboratories, Mt. Vernon, ME) following the $\mathrm{CO}_{2}$ Burst Respiration protocol (Haney and Haney, 2010). Soil nitrate was measured using extraction with a $0.04 \mathrm{M}$ ammonium sulfate solution (Griffin et al., 2011) followed by spectrophotometric analysis of the extract using the vanadium reduction method (Doane and Horwath, 2003).

Statistical analysis. Yield data were transformed using $\log (x+1)$ to normalize the distribution before using the analysis of variance (ANOVA) procedure in SAS (Statistical 
Analysis System Inst., Cary, NC). Fisher's least significant difference test was used to compare the reduced tillage treatments to the control. Differences between treatments for the Cornell Soil Health Test results were evaluated by percent change over the 3-year study. Statistical differences for respiration and nitrate data were determined using repeated measures ANOVA with sampling time as the repeated variable. Treatment means were compared using paired comparisons of least squares.

\section{Results}

\section{Yields}

The main objective of our study was to identify reduced tillage treatments which yielded as well or better than the conventional control. Because there was a significant interaction between treatment and years $(P<$ $0.0001)$ for yield, individual years were analyzed separately.

Tomato. In 2011, the control plots had an average total yield of $40 \mathrm{t} \cdot \mathrm{ha}^{-1}$. Only the strip tillage treatment, which yielded $12 \mathrm{t} \cdot \mathrm{ha}^{-1}$, differed significantly from the control in total yield (Fig. 1). Although not significant, total yields in the perennial living mulch treatment were lower than the control at only $22 \mathrm{t} \cdot \mathrm{ha}^{-1}$. Both the perennial living mulch and strip tillage treatments had significantly lower total yields than the conventional control in 2012, when the total yields for the control plots averaged $66 \mathrm{t} \cdot \mathrm{ha}^{-1}$ (Fig. 1). Annual living mulch treatment yields did not differ from the control in either year. The percentage of fruit that was marketable did not differ between treatments in either year, averaging $75 \%$ in 2011 and $65 \%$ in 2012. In 2011, fruit size did not differ between treatments, but in 2012, both the perennial living mulch and strip tillage treatments had significantly smaller fruit than the control.

Cabbage. All undamaged heads greater than $9 \mathrm{~cm}$ in diameter were considered marketable. In 2011, the direct-seeded cabbage established poorly, resulting in general crop failure. In 2012, the cabbage were transplanted. Total yields in the control and annual living mulch treatments were 35 and $41 \mathrm{t} \cdot \mathrm{ha}^{-1}$, respectively. The control yielded

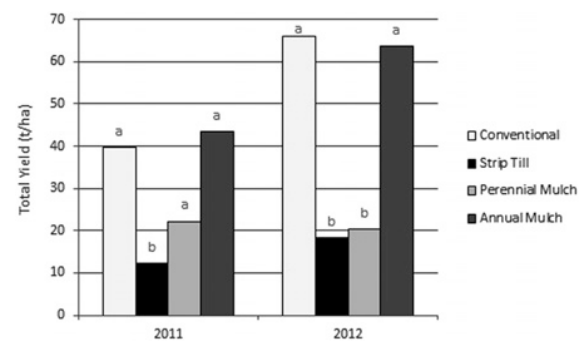

Fig. 1. Total yield for tomatoes in the four tillage treatments in 2011 and 2012. Data are averaged across three replications. Within a year, columns with the same letter are not significantly different. Data were transformed using log (value +1 ) for analysis, but actual yields are reported. significantly more than the strip tillage $\left(6 \mathrm{t} \cdot \mathrm{ha}^{-1}\right)$ and perennial living mulch $\left(9 \mathrm{t} \cdot \mathrm{ha}^{-1}\right)$ treatments. Head size averaged $1.2 \mathrm{~kg}$ in the control treatment and $1.3 \mathrm{~kg}$ in the annual living mulch treatment, but only $0.4 \mathrm{~kg}$ in the other treatments. Marketable yields ranged from $92 \%$ to $96 \%$ of total yields.

Cucurbits. Both cucumbers and melons followed the same pattern for total yields, with the perennial and annual mulch treatments not differing from the conventional treatment in either year, and the strip tillage treatment yielding very poorly in both years (Fig. 2). In 2011, total yields for the control treatment averaged $17 \mathrm{t} \cdot \mathrm{ha}^{-1}$ for melons and $58 \mathrm{t} \cdot \mathrm{ha}^{-1}$ for cucumbers; 2012 yields were 24 and $36 \mathrm{t} \cdot \mathrm{ha}^{-1}$ for melons and cucumbers, respectively. Differences in yields between the control treatment and the strip tillage treatment were significant, with the exception of the 2012 cucumber yields, where striped cucumber beetle (Acalymma vittatum) feeding damage and associated bacterial wilt resulted in high variability between replications.

For cucumbers, marketable yield was $45 \%$ of total in the control treatment in 2011 , and $67 \%$ of total in 2012 . None of the treatments differed significantly from the control in either year. Unmarketable fruit were primarily due to cucumber beetle damage. Melon marketable yield was $66 \%$ of total yield in the control treatment in 2011, but only $27 \%$ of total yield in 2012. Marketable yield in the strip-tillage treatment was significantly lower than the other treatments in 2011, and significantly lower than the living mulch treatments in 2012. Unmarketable fruit mostly failed to ripen before vine health declined, resulting in very low sugar levels.

Lettuce and carrots. Only 2012 data are available for the lettuce and carrots because heavy predation by mice and voles resulted in
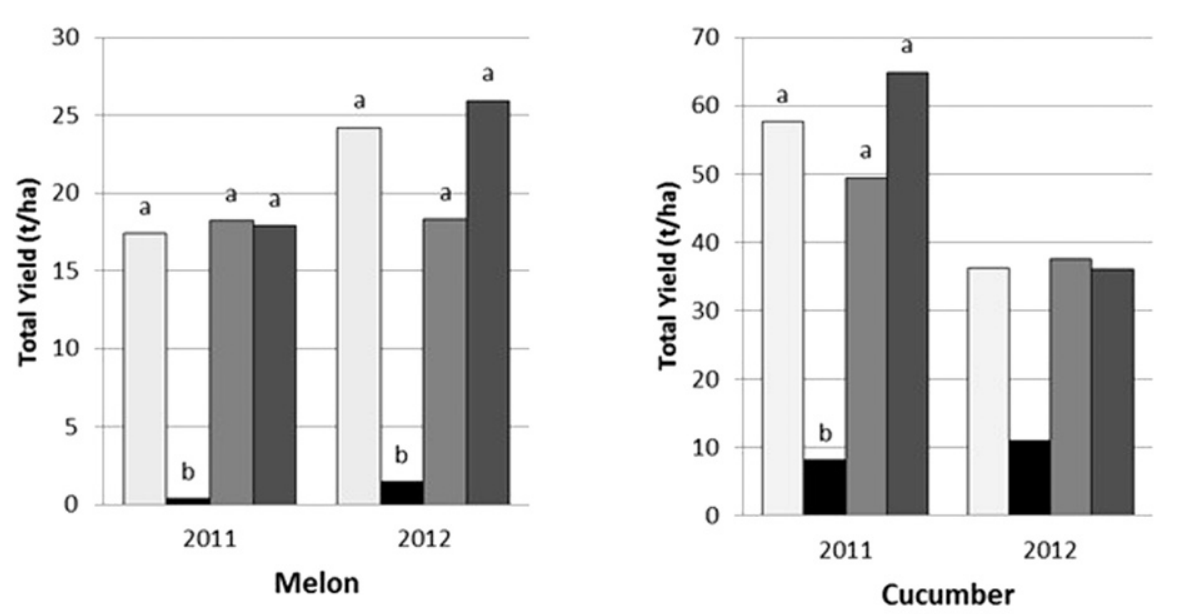

$\square$ Conventional $\quad$ Strip Till $\square$ Perennial Mulch $\square$ Annual Mulch

Fig. 2. Total yield for melons and cucumbers. In 2012, differences in cucumber yields between treatments were not significant due to a gradient effect from cucumber beetle damage that led to high variability among replications. Data are averaged across three replications. Within a year, columns with the same letter are not significantly different. Data were transformed using $\log ($ value +1$)$ for analysis, but actual yields are reported.

repeated crop failures in 2011. In 2012, the control treatment and the annual living mulch treatment each yielded $2 \mathrm{t} \cdot \mathrm{ha}^{-1}$ of lettuce. Both significantly outyielded the strip till and perennial living mulch treatments, which produced 0.1 and $0.4 \mathrm{t} \cdot \mathrm{ha}^{-1}$, respectively. All of the harvested lettuce was marketable, as is typical with baby greens.

Total carrot yields ranged from $12 \mathrm{t} \cdot \mathrm{ha}^{-1}$ for the annual living mulch treatment to $4 \mathrm{t} \cdot \mathrm{ha}^{-1}$ for the strip till treatment. However, only $62 \%$ of the yield in the annual living mulch treatment was marketable. Percent marketability was $82 \%$ for the control and $88 \%$ for the perennial living mulch, with the result that marketable yields were comparable for the conventional, perennial living mulch, and annual living mulch treatments. Although the marketable yield of these treatments was 2.3 times that of the strip till treatment, variation between plots was such that there were no significant treatment effects.

\section{Soil health}

Cornell Soil Health Test. The Cornell Soil Health Test is a comprehensive analysis incorporating 12 different indicators that is designed to monitor changes in soil chemical, biological, and physical properties over the long term (Idowu et al., 2009). Samples are collected once a year, in the spring. Before treatment initiation, the overall soil quality was medium with an average score of 62.7 out of 100 across the three replications. Ratings for individual physical and chemical properties were medium to high, but those for biological properties were low, with the exception of potentially mineralizable nitrogen. Most of the soil property ratings were within the normal range throughout the study and were not significantly affected by the tillage reduction treatments (Table 1). Tillage reduction did significantly affect aggregate 
stability, potentially mineralizable nitrogen, active carbon, and soil organic matter.

At the beginning of the study in 2010 , soil aggregate stability values averaged $45 \%$, which corresponds to a rating of 69 out of 100 , just below the optimal quality range. Aggregate stability decreased in all treatments during the first year of the study, but remained within the range for medium quality. Stability increased in the 2nd and 3rd years of the study in the strip tillage and perennial living mulch treatments, but not in the conventional or annual living mulch treatments (Fig. 3). The strip tillage treatment raised aggregate stability into the optimal range, resulting in significantly greater aggregate stability than in the conventional control in both 2012 and 2013. The aggregate stability in the annual and perennial living mulch treatments was similar to the control in all years; all three treatments remained in the medium range. In the strip tillage treatment, aggregate stability at the conclusion of the study was higher $(P=0.09)$ than at the beginning of the study; none of the other treatments experienced significant change over time.

At the start of the study, potentially mineralizable nitrogen levels were medium to high, averaging $12 \mu \mathrm{g} \mathrm{N} / \mathrm{g}$ soil. Over the course of the study, mineralizable nitrogen levels increased in the strip tillage treatment $(P=0.099)$ and the perennial living mulch treatment $(P=0.001)$ and decreased in the annual living mulch treatment $(P=0.041)$. Levels decreased from 2010 to 2011 in the conventional control. They increased from 2011 to 2012 and then decreased again from 2012 to 2013, resulting in no overall change. (Fig. 4). None of the treatments differed significantly from the control in 2011 and 2012. In 2013, the strip tillage treatment had significantly more potentially mineralizable nitrogen than the control and the annual living mulch treatments. Both the strip tillage and the perennial living mulch treatments had potentially mineralizable nitrogen levels in the high range at the end of the study, whereas levels in the other treatments were low.

Table 1. Soil health ratings for indicators that were not significantly affected by the tillage reduction treatments. The Cornell Soil Health Test uses a 100-point rating scale where higher scores reflect better soil health; scores below 30 are considered poor, 30 to 70 are intermediate, and 70 to 100 are optimal (Idowu et al., 2009). Soil was sampled in April of each year; ratings are means across all plots.

\begin{tabular}{lrrrr}
\hline & \multicolumn{4}{c}{ Yr } \\
\cline { 2 - 5 } Indicator & 2010 & 2011 & 2012 & 2013 \\
\hline Available water capacity & 52 & 66 & 92 & 88 \\
Surface hardness & 72 & 94 & 52 & 62 \\
Subsurface hardness & 85 & 95 & 76 & 74 \\
Root health rating & 34 & 64 & 64 & 54 \\
pH & 70 & 81 & 83 & 86 \\
Extractable phosphorus & 100 & 100 & 100 & 100 \\
Extractable potassium & 59 & 95 & 100 & 100 \\
Minor elements & 100 & 100 & 100 & 100 \\
\hline
\end{tabular}

Differences between treatments in active carbon were significant only in 2013, when the strip tillage treatment had significantly more active carbon than the control. The patterns of change in active carbon from 2011 to 2013 also differed $(P=0.056)$. Carbon levels increased by $14 \%$ and $16 \%$ in the perennial living mulch and strip tillage treatments, respectively, and decreased by $8 \%$ and $10 \%$ in the conventional control and annual living mulch treatments, respectively (Fig. 5). Active carbon levels were lower than recommended by Cornell University throughout the study.
Before study establishment, the soil organic matter content in the field ranged from $2.9 \%$ at the western end to $3.4 \%$ at the eastern end, with an average value of $3.1 \%$. This is within the typical range for soils in Rhode Island with a history of row crop production (Wright and Sautter, 1988), and is at the low end of the medium quality range on the Cornell Soil Health Test. To compensate for this gradient, the treatment effect was analyzed as the percent change in soil organic matter. Soil organic matter levels decreased in all treatments from 2011 to 2012, with the greatest decrease in the conventional control

60

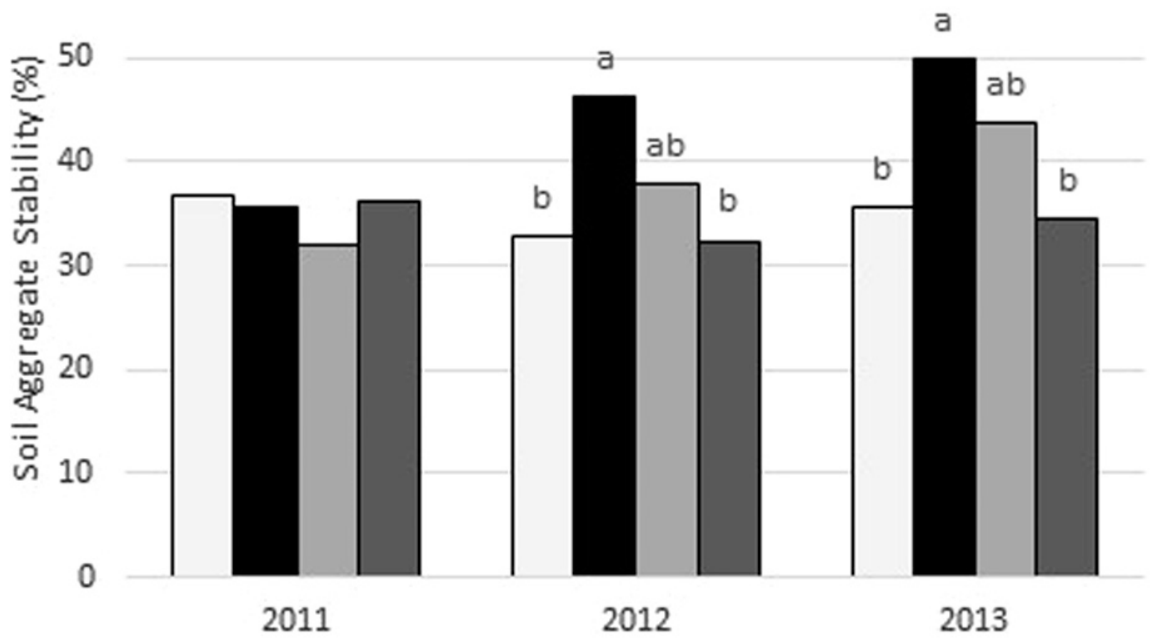

口Conventional -Strip Till aPerennial Mulch aAnnual Mukch

Fig. 3. Soil aggregate stability differences between tillage treatments. Stability was measured from samples collected in April of each year; bars represent the means of three replications. Within a year, letters indicate significant differences at $\alpha=0.05$. There were no significant differences in 2011. The increase in aggregate stability over time in the strip tillage treatment was significant at $\alpha=0.1$.

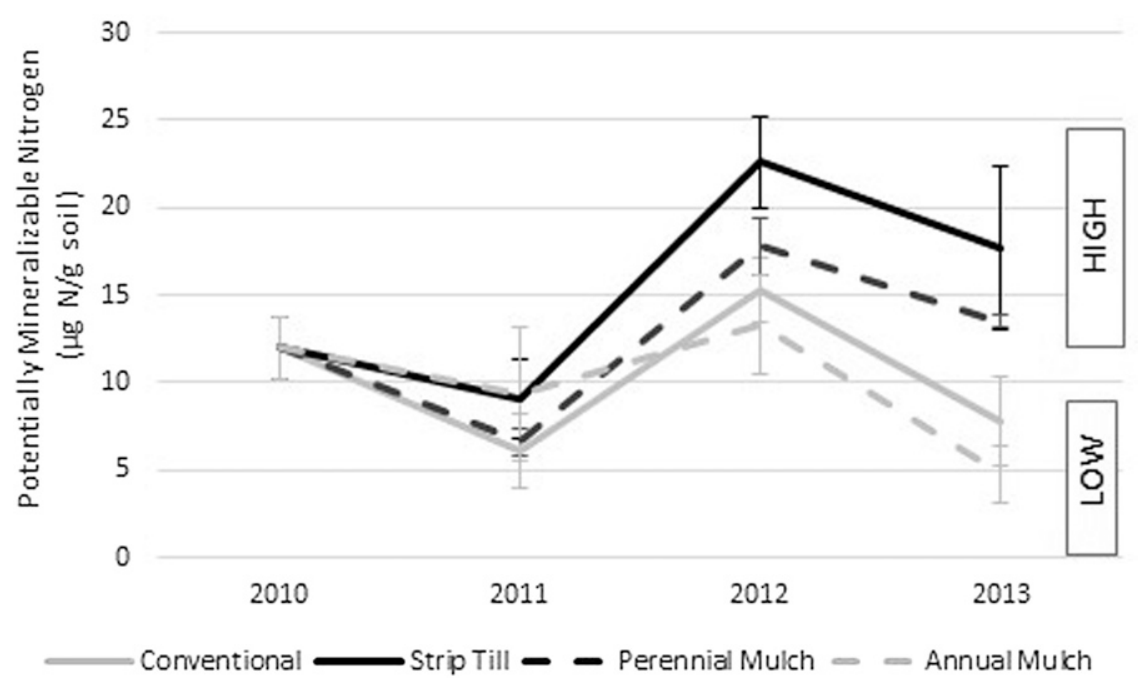

Fig. 4. Effects of year and treatment on potentially mineralizable nitrogen. Data are means of three replications. Letters indicate significant differences in 2013; there were no significant differences in other years. Levels below $9.5 \mu \mathrm{g} \mathrm{N} / \mathrm{g}$ soil are considered to be low, while levels above $11.5 \mu \mathrm{g} \mathrm{N} / \mathrm{g}$ soil are high (Idowu et al., 2009). 
(Fig. 6). Levels continued to decrease in the conventional control and annual living mulch treatments from 2012 to 2013, but remained constant in the strip tillage and perennial living mulch treatments. Overall, the strip tillage and perennial living mulch treatments lost significantly smaller percentages of the initial soil organic matter than did the conventional control and annual living mulch treatments.

Microbial activity. Data were analyzed separately for 2011 and 2012, as treatment interacted with the climate differences between the 2 years. The perennial living mulch treatment had the highest $\mathrm{CO}_{2}$ respiration rate in 2011 , averaging $34.7 \mu \mathrm{g} \mathrm{CO}_{2} / \mathrm{g}$ soil/ day (Table 2). Only the perennial living mulch treatment was significantly different from the control.

In 2012, all three reduced tillage treatments resulted in significantly higher $\mathrm{CO}_{2}$ respiration than in the control (Table 2).

Nitrate. There was no effect of crop on soil nitrate levels. Levels of nitrate did differ between years, and the year $\times$ treatment interaction was significant. Nitrate levels followed a similar pattern over the course of the growing season in 2011 and 2012, peaking in late June and early July, then decreasing to a few $\mu \mathrm{g} \mathrm{N} / \mathrm{g}$ soil. However, soil nitrate levels in 2012 were significantly higher than 2011 levels in all treatments, likely due to the additional fertilizer applied in 2012 after the 2011 tomatoes developed nitrogen-deficiency symptoms. The annual living mulch treatment had the highest nitrate levels, significantly higher than the conventional control in both years (Table 3 ). In 2011, the strip tillage and perennial living mulch treatments were similar to the conventional control, but in 2012 they were significantly lower than the control.

\section{Discussion}

Conventional control. As expected, the conventional practice of thorough tillage before planting, coupled with regular cultivation within and between rows, was successful in producing vegetables. None of the alternative treatments had significantly higher yields than the control treatment. However, the repeated soil disruption reduced soil organic matter, and consequently aggregate stability, microbial activity, potentially mineralizable nitrogen, and active carbon. These effects of tillage are well documented (Cannell and Hawes 1994; Magdoff and van Es, 2009). It is worth noting that the winter cover crop of cereal rye was not sufficient to ameliorate the negative effects of tillage on soil organic matter. The cover crop is generally incorporated as a green manure, usually before heading. Green manures have less lignin and a lower $\mathrm{C}: \mathrm{N}$ ratio than straw (Pinck et al., 1950) but have been shown to increase soil carbon in corn and grain systems (MacRae and Mehuys, 1985; Paustian et al., 1992).

Strip tillage. The strip tillage treatment was the most effective at promoting soil health, and was the only treatment to significantly outperform the control for most

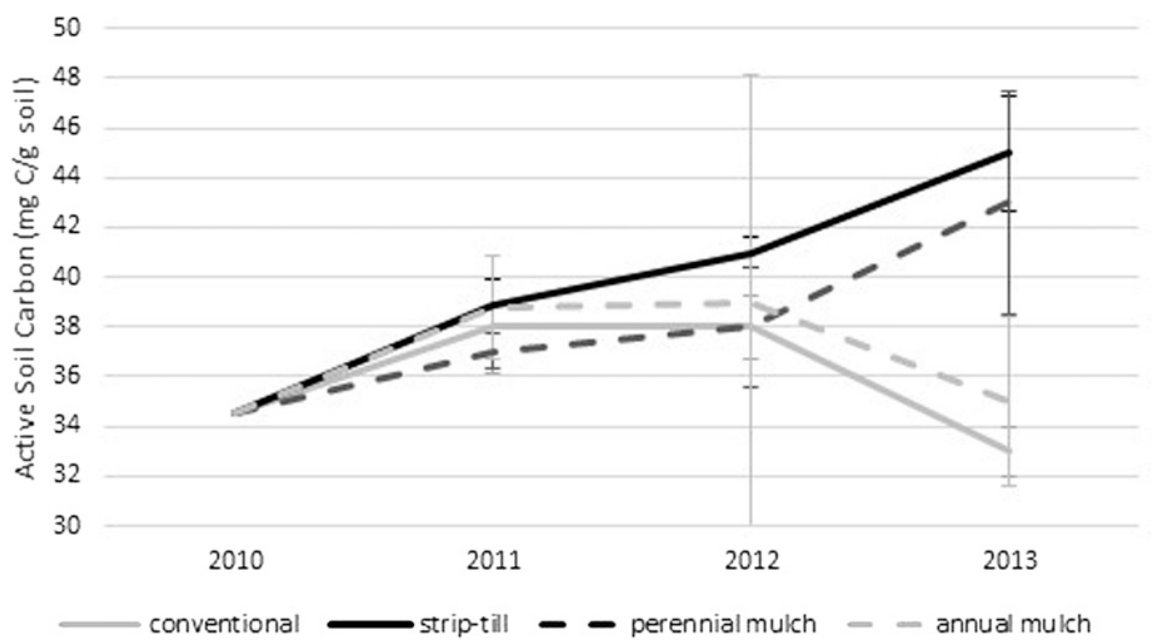

Fig. 5. Effects of treatment on soil active carbon levels over time. Data are means of three replications. Letters indicate significant differences in 2013; there were no significant differences in other years. Values below $50 \mathrm{mg} \mathrm{C/g}$ soil are lower than recommended (Idowu et al., 2009).

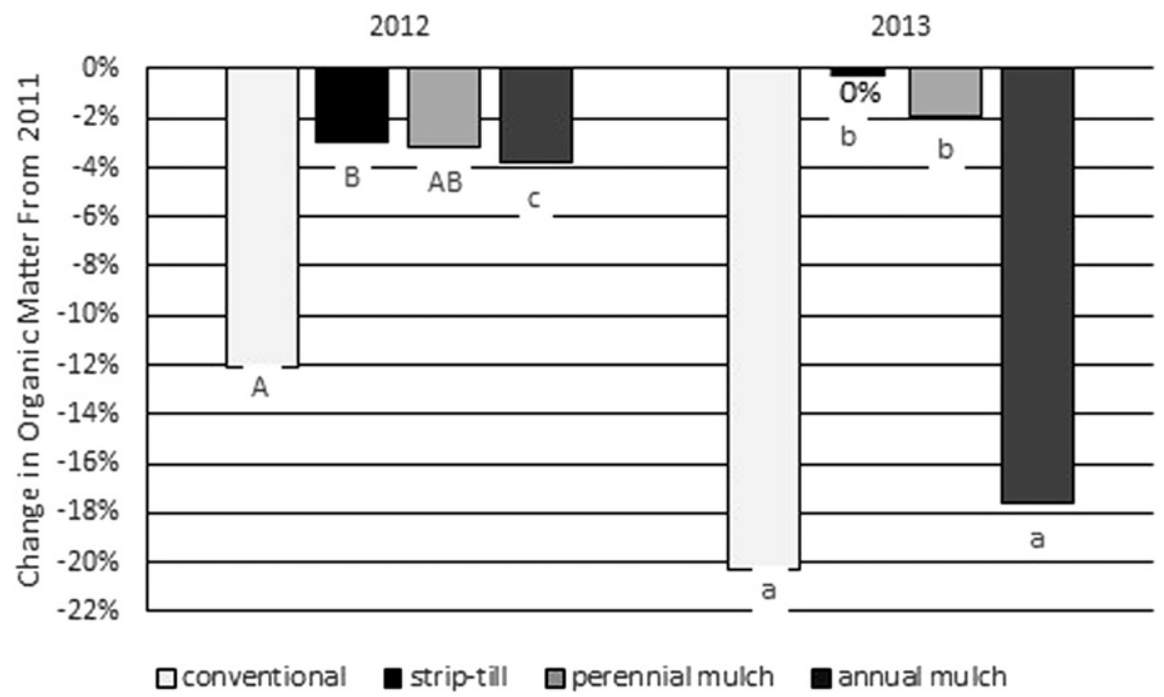

Fig. 6. Effects of treatment on soil organic matter levels, represented as percentage change in soil organic matter (SOM) from 2011 levels. Data are the means of three samples per treatment. In 2011, average SOM values were $3.3 \%, 3.4 \%, 3.1 \%$, and $3.4 \%$ in the conventional control, strip tillage, perennial living mulch, and annual living mulch treatments, respectively. Within a year, columns with the same letter are not significantly different at $\alpha=0.1$.

components of soil health. However, strip tillage was not effective for production of vegetables, with the strip-tillage plots having the lowest yields throughout the study. Low yields were likely due to failure of the cereal rye mulch to suppress weeds throughout the growing season (data not shown). Although weeds were removed by hand pulling within the planting strips cut by the zone builder, no cultivation was done between the strips. Since the planting strips were only $30 \mathrm{~cm}$ in width, the crops faced considerable competition for light. Other researchers have found cover crop residue to be as effective as herbicide applications in controlling weeds (Hoyt, 1999; Hoyt et al., 1994; Morse, 1999) but control was dependent on achieving cover crop biomass levels of 6.7-13.4 Mg.ha ${ }^{-1}$.
In this study, biomass levels averaged only $1.7 \mathrm{Mg} \cdot \mathrm{ha}^{-1}$ in 2011 and $2.1 \mathrm{Mg} \cdot \mathrm{ha}^{-1}$ in 2012. Teasdale and Mohler (2000) showed an exponential relationship between rye mulch biomass and weed populations, concluding that weed suppression is increased by $15 \%$ for every $1000 \mathrm{~kg}$ of cover crop biomass. Increasing the rye seeding rate by $50 \%$ had minimal effect on biomass levels in agreement with the findings of Masiunas et al. (1995) and Boyd et al. (2009) that initial seeding rate has only limited effect on rye biomass at anthesis. In contrast, Mirsky et al. (2011) found that fall planting date significantly affected rye biomass at all spring termination times, including termination after anthesis. Biomass production in their study, conducted in eastern Pennsylvania, 
Table 2. Least squares means $(n=48)$ and pairwise comparisons of differences for soil respiration ( $\mu \mathrm{g} \mathrm{CO}_{2} / \mathrm{g}$ soil/day) measured over time using the Solvita ${ }^{\circledR}$ soil respiration kit. Data are from samples collected every 2 weeks during the growing season and represent 12 sampling dates in 2011 and 13 in 2012. The reduced tillage treatments were compared with the conventional control treatment.

\begin{tabular}{llc}
\hline & \multicolumn{2}{c}{ Yr } \\
\cline { 2 - 3 } Treatment & 2011 & 2012 \\
\hline Conventional & 27.0 & 23.9 \\
Strip till & 30.0 & $35.4^{* *}$ \\
Perennial mulch & $34.7^{*}$ & $31.5^{* *}$ \\
Annual mulch & 30.0 & $28.4^{*}$ \\
\hline
\end{tabular}

*Significant at $\alpha=0.05$.

**Significant at $\alpha=0.001$.

Table 3. Least squares means $(n=48)$ and pairwise comparisons of differences for soil nitrate levels $(\mu \mathrm{g} \cdot \mathrm{N} / \mathrm{g}$ soil) measured over time. In 2011, samples were collected biweekly from 29 June to 7 Oct.; 2012 samples were collected biweekly from 20 Apr. to 12 Oct. Reduced tillage treatments were compared with the conventional control treatment.

\begin{tabular}{lll}
\hline & \multicolumn{2}{c}{ Yr } \\
\cline { 2 - 3 } Treatment & 2011 & \multicolumn{1}{c}{2012} \\
\hline Conventional & 1.41 & 4.64 \\
Strip till & 1.25 & $2.84^{* *}$ \\
Perennial mulch & 1.19 & $3.23^{*}$ \\
Annual mulch & $1.89^{*}$ & $7.46^{* *}$ \\
\hline
\end{tabular}

*Significant at $\alpha=0.05$.

$* *$ Significant at $\alpha=0.001$.

decreased by $36 \%$ when rye was planted on 15 Oct. instead of 25 Aug., with particularly strong decreases in biomass production associated with planting after 25 Sept. The effects of delayed planting would be expected to be even greater in our location, as we are further north. In our study, harvesting of tomatoes, carrots, and lettuce continued into midSeptember, and cabbage was harvested 1 Oct., so earlier seeding of the rye would require earlier termination of the vegetable crops.

Yield reductions in the strip tillage treatment may also have been due to nitrogen immobilization by the cover crop mulch and reduced decomposition and nitrogen mineralization due to cooler soils. Nitrate levels were significantly lower in the strip tillage treatment than the conventional treatment in 2012, despite having significantly higher levels of potentially mineralizable nitrogen and microbial activity. Others have reported nitrogen immobilization to be an issue with crops planted into killed cover crop mulches (Bottenberg et al., 1999; Masiunas 1998). Killed cover crop mulches have also been reported to reduce soil temperatures, which can slow growth of spring-planted crops (Masiunas, 1998). However, in our study the strip tillage treatment had the highest average soil temperature; treatment averages differed by less than $1{ }^{\circ} \mathrm{C}$.

Perennial living mulch. The perennial living mulch treatment produced yields comparable to the conventional treatment for the cucurbits in both years, and for the carrots in 2012. Over the 4 years of the study, potentially mineralizable nitrogen increased. Soil organic matter decreased less than in the conventional treatment and microbial activity was higher. Nitrate was lower than the control and may have limited crop growth. Where the perennial ryegrass and white clover living mulch was present, it successfully limited and smothered broadleaf weeds. As the experiment progressed, however, it became difficult to control competition in the transition zone between the living mulch and the planting bed. Competition was less of a problem in beds covered with black plastic mulch, but the mechanical bed maker/mulch layer destroyed the perennial living mulch for $15 \mathrm{~cm}$ on either side of the bed. We laid plastic mulch for the cucurbits by hand to avoid disturbing the living mulch, but this labor-intensive solution would be uneconomical in a production operation. One option for economically combining perennial living mulch with plastic mulch covered beds would be to leave the plastic in place for multiple years. This strategy has been successfully implemented in Maine (Bryant, 2008). In beds without plastic mulch, this system is similar to many fall-planted living mulch systems used in corn and other crops. Suppression of the living mulch during the rapid vegetative growth stage of the crop is key to success in these systems (Masiunas, 1998). Grubinger and Minotti (1990) found that rototilling was more effective than mowing at suppressing a white clover living mulch to prevent competition with sweet corn.

Annual living mulch. Yields in the annual living mulch treatment were comparable to the control treatment; soil health indicators were also similar, with the exception of nitrate levels which were significantly higher in the annual living mulch treatment. The lack of improvement in soil health was likely due to the relatively low biomass production of the spring-seeded crimson clover. Masiunas (1998) reported that spring-seeded living mulches provided less competition for vegetable crops than fall-seeded living mulches. Use of living mulches in vegetables and nonlegume crops has largely been limited to clovers and other legumes that suppress weeds and add nitrogen, but may do little to build soil organic matter (Hartwig and Ammon, 2002; Ilnicki and Enache, 1992; Masiunas, 1998).

In conclusion, our study showed that, while strip tillage into killed cover crops or perennial living mulch has potential for improving soil health, it results in reduced vegetable yields compared with the control treatment. Yield reductions are probably due to competition with weeds and the living mulch, and possibly due to reduced soil nitrate or changes in soil temperature and moisture. Most strip tillage production systems rely on herbicides to reduce competition (Hoyt et al., 1994; Masiunas, 1998). Production of sufficient cover crop biomass will also be a limiting factor for use of killed cover crop biomass in regions with short growing seasons or where vegetable production continues into the fall. Annual living mulches of crimson clover provide nitrogen to vegetable crops, and interseeding clover after planting vegetables could permit the incorporation of legumes into vegetable systems where the cash crop remains in the field too long to permit establishment of a winter cover crop of hairy vetch, but annual living mulches are not effective for preserving soil organic matter. Furthermore, none of the reduced tillage systems was able to increase soil organic matter over the 3 years of this study, suggesting that tillage reduction is not a valid alternative to rotating fields into highbiomass summer cover crops or pasture to build soil organic matter.

\section{Literature Cited}

Abdul-Baki, A.A. and J.R. Teasdale. 2007. Sustainable production of fresh-market tomatoes and other vegetables with cover crop mulches. USDA ARS Farmers' Bul. 2280.

Baker, J.M., T.E. Ochsner, R.T. Venterea, and T.J. Griffis. 2007. Tillage and soil carbon sequestration-What do we really know? Agriculture, Ecosystems \& Environment. 118(1): $1-5$.

Bottenberg, H., J. Masiunas, and C. Eastman. 1999. Strip tillage reduces yield loss of snapbean planted in rye mulch. HortTechnology 9:235-240.

Boyd, N.S., E.B. Brennan, R.F. Smith, and R. Yokota. 2009. Effect of seeding rate and planting arrangement on rye cover crop and weed growth. Agron. J. 101(1):47-51.

Bryant, H.D. 2008. Hybrid mulch system: Effects on crop production, economics, weeds and soil quality. Univ. of Maine Orono, Master of Sci. Thesis Diss. 1133.

Cannell, R.Q. and J.D. Hawes. 1994. Trends in tillage practices in relation to sustainable crop production with special reference to temperate climates. Soil Tillage Res. 30(2):245-282.

Doane, T.A. and W.R. Horwath. 2003. Spectrophotometric determination of nitrate with a single reagent. Anal. Lett. 36(12):2713-2722

Griffin, G., W. Jokela, D. Ross, D. Pattrinelli, T Morris, and A. Wolf. 2011. Recommended soil nitrate tests, p. 27-38. In: Recommended soil testing procedures for the northeastern United States. 3rd ed. Northeastern Regional Publication 493.

Grubinger, V.P. and P.L. Minotti. 1990. Managing white clover living mulch for sweet corn production with partial rototilling. Amer. J. Altern. Agr. 5:4-12.

Gugino, B.K., O.J. Idowu, R.R. Schindelbeck, H.M. van Es, D.W. Wolfe, B.N. Moebius-Clune, J.E. Thies, and G.S. Abawi. 2009. Cornell soil health assessment training manual. 2nd ed. Cornell Univ., Geneva, NY.

Haney, R.L. and E.B. Haney. 2010. Simple and rapid laboratory method for rewetting dry soil for incubations. Commun. Soil Sci. Plant Anal. 41(12):1493-1501

Hartwig, N.L. and H.U. Ammon. 2002. Cover crops and living mulches. Weed Sci. 50(6): 688-699.

Havlin, J.L., D.E. Kissel, L.D. Maddux, M.M Claassen, and J.H. Long. 1990. Crop rotation and tillage effects on soil organic carbon and nitrogen. Soil Sci. Soc. Amer. J. 54(2):448452.

Horowitz, J., R. Ebel, and K. Ueda. 2010. No-till farming is a growing practice. USDA-ERS Economic Info. Bul. 70. 
Howell, J. (ed.). 2010. New England vegetable management guide. New England extension systems, Univ. of Massachusetts, Amherst, MA.

Hoyt, G.D., D.W. Monks, and T.J. Monaco. 1994. Conservation tillage for vegetable production. HortTechnology 4:129-135.

Hoyt, G.D. 1999. Tillage and cover residue effects on vegetable yields. HortTechnology 9:351358.

Idowu, O.J., H.M. van Es, G.S. Abawi, D.W. Wolfe, R.R. Schindelbeck, B.N. MoebiusClune, and B.K. Gugino. 2009. Use of an integrative soil health test for evaluation of soil management impacts. Renew. Agr. Food Syst. 24:214-224.

Ilnicki, R.D. and A.J. Enache. 1992. Subterranean clover living mulch:an alternative method of weed control. Agr. Ecosyst. Environ. 40(1): 249-264.

MacRae, R.J. and G.R. Mehuys. 1985. The effect of green manuring on the physical properties of temperate-area soils. Adv. Soil Sci. 3:71-94.

Magdoff, F. and H. van Es. 2009. Building soils for better crops: Sustainable soil management. Sustainable Agriculture Publications, Waldorf, MD.
Masiunas, J.B. 1998. Production of vegetables using cover crop and living mulches. J. Veg. Prod. 4(1):11-31.

Masiunas, J.B., L.A. Weston, and S.C. Weller. 1995. The impact of rye cover crops on weed populations in a tomato cropping system. Weed Sci. 43(2):318-323.

Mirsky, S.B., W.S. Curran, D.M. Mortenseny, M.R. Ryany, and D.L. Shumway. 2011. Timing of cover-crop management effects on weed suppression in no-till planted soybean using a roller-crimper. Weed Sci. 59(3):380-389.

Mitchell, J.P., K.M. Klonsky, E.M. Miyao, B.J. Aegerter, A. Shrestha, D.S. Munk, K. Hembree, N.M. Madden, and T.A. Turini. 2012. Evolution of conservation tillage systems for processing tomato in California's Central Valley. HortTechnology 22:617-626.

Mitchell, J., A. Shrestha, M. Campbell-Mathews, D. Giacomazzi, S. Goyal, D. Bryant, and I. Hererra. 2009. Strip-tillage in California's Central Valley. Univ. of California Division of Agriculture and Natural Resources Publ. 8361.

Morse, R.D. 1999. No-till vegetable productionits time is now. HortTechnology 9:373-379.

Nair, A., D. Jokela, and J. Tillman. 2014. Principles and practices of sustainable vegetable production systems, p. 51-78. In: D. Nandwani (ed.). Sustainable horticultural systems. Springer International Publishing.

Paustian, K., W.J. Parton, and J. Persson. 1992. Modeling soil organic matter in organicamended and nitrogen-fertilized long-term plots. Soil Sci. Soc. Amer. J. 56(2):476488.

Pinck, L.A., F.E. Allison, and M.S. Sherman. 1950. Maintenance of soil organic matter: II. Losses of carbon and nitrogen from young and mature plant materials during decomposition in soil. Soil Sci. 69(5):391-402.

Stubbs, T.L., A.C. Kennedy, and W.F. Schillinger. 2004. Soil ecosystem changes during the transition to no-till cropping. J. Crop Imp. 11(1-2): 105-135.

Teasdale, J.R. and C.L. Mohler. 2000. The quantitative relationship between weed emergence and the physical properties of mulches. Weed Sci. 48:385-392.

USDA, NASS. 2012. Census of Agriculture. United States Department of Agriculture. 12 Oct. 2015. $<$ http://www.agcensus.usda.gov/index.php $>$.

Wright, W.R. and E.H. Sautter. 1988. Soils of Rhode Island landscapes. Univ. of Rhode Island Agr. Ext. Sta. Bul. 429. 